\title{
In vitro culture of shoot apices from juvenile and adult yellow passion fruit plants
}

\author{
Tatiana G. Junghans ${ }^{1}$, Solange R. M. de Andrade ${ }^{2}$, Karine da S. Simões ${ }^{3}$,
} Celma dos S. Caldas ${ }^{3}$, Antônio da S. Souza², Carlos A. da S. Ledo²

\footnotetext{
${ }^{1}$ Embrapa Mandioca e Fruticultura, Rua Embrapa, s/n, Centro, CEP 44380000, Cruz das Almas-BA, Brasil. Caixa Postal 007. E-mail: tatiana.junghans@embrapa.br; antonio.silva-souza@embrapa.br; carlos.ledo@embrapa.br

${ }^{2}$ Empresa Brasileira de Pesquisa Agropecuária, Centro de Pesquisa Agropecuária dos Cerrados, BR 020, km 18, Planaltina, CEP 73310-970, Brasília-DF, Brasil. Caixa Postal 08223. E-mail: solange.andrade@embrapa.br

${ }^{3}$ Universidade Federal do Recôncavo da Bahia, Centro de Ciências Agrárias, Ambientais e Biológicas, Campus Universitário, CEP 44380-000, Cruz das Almas-BA, Brasil. E-mail: cayss7@hotmail.com; celmacruzdasalmas@hotmail.com
}

\section{ABSTRACT}

The aim of the present study was to evaluate in vitro plant regeneration from the shoot apices of juvenile and adult passion fruit plants and provide a basis for future clonal cleanup of superior genotypes through the use of tissue culture. The studies were divided into three experiments to evaluate the effect of age and origin of the donor plant, the culture medium methodology and the size of the explants. The shoot apices were inoculated in Murashige \& Skoog (MS) medium with 3\% sucrose and three 6-benzylaminopurine (BAP) concentrations: 0 , 1 or $2 \mathrm{mg} \mathrm{L}^{-1}$. Next, the samples were transferred to a half-strength mineral salt medium ( $1 / 2 \mathrm{MS}$ ) and supplemented with $1 \mathrm{mg} \mathrm{L}^{-1}$ indolebutyric acid (IBA). Two cultivation methods were used: one with variations in the cultivation period in the MS medium (26 or 60 days) and the other with or without transfer to half-strength mineral salt medium ( $1 / 2 \mathrm{MS})$. The methodology by which explants are maintained in MS medium supplemented with $1 \mathrm{mg} \mathrm{L}^{-1}$ BAP for 26 days, followed by transfer to $1 / 2 \mathrm{MS}$ medium supplemented with $1 \mathrm{mg} \mathrm{L}^{-1}$ IBA for 21 days of cultivation and then transfer to $1 / 2$ MS medium for 14 days is more appropriate for regenerating plants from the shoot apices of adult Passiflora edulis (AGBP accession 38).

Key words: growth regulators, Passiflora edulis, tissue culture

\section{Cultivo in vitro de ápices caulinares provenientes de plantas jovens e adultas de maracujazeiro amarelo}

\section{RESUMO}

O objetivo deste trabalho foi avaliar a regeneração de plantas in vitro a partir de ápices caulinares provenientes de maracujazeiros jovens e adultos e fornecer subsídios para futuros trabalhos de limpeza clonal de genótipos superiores, via cultura de tecidos. Os estudos foram divididos em três experimentos visando avaliar o efeito da idade e a procedência da planta doadora, da metodologia do meio de cultivo e do tamanho dos explantes. Os ápices caulinares foram inoculados em meio de estabelecimento Murashige \& Skoog (MS), acrescido de 3\% de sacarose e com três concentrações de BAP: 0; $1 \mathrm{mg} \mathrm{L}^{-1}$ ou $2 \mathrm{mg} \mathrm{L}^{-1}$. Em seguida, foram transferidos para o meio com metade das concentrações dos sais minerais (1/2MS) acrescida de $1 \mathrm{mg} \mathrm{L}^{-1}$ de AIB. Duas formas de cultivo foram utilizadas variando o período de cultivo no meio de estabelecimento ( 60 dias ou 26 dias) e a transferência ou não para o meio, com metade das concentrações dos sais minerais (1/2MS). A metodologia na qual os explantes são mantidos em meio MS acrescido de $1 \mathrm{mg} \mathrm{L}^{-1}$ de BAP durante 26 dias seguidos de transferência para o meio $1 / 2 \mathrm{MS}$ acrescido de $1 \mathrm{mg} \mathrm{L}^{-1}$ de $\mathrm{AIB}$, por 21 dias de cultivo e, posteriormente, para o meio $1 / 2 \mathrm{MS}$, por 14 dias, é mais apropriada para regenerar plantas a partir de ápices caulinares de plantas adultas de Passiflora edulis (acesso BGP 38).

Palavras-chave: reguladores de crescimento, Passiflora edulis, cultura de tecidos 


\section{Introduction}

The yellow or sour passion fruit (Passiflora edulis Sims) is the main specie of commercially produced passion fruit. This species is cultivated in almost all of Brazil, but the main producers are the states of Bahia, Sergipe, São Paulo, Pará and Minas Gerais, that together are responsible for Brazil's leadership in the world production of this fruit (Meletti et al., 2005).

A limiting factor in the cultivation of passion fruit is the presence of viruses in most orchards. The disease can be caused by two virus species: Passion fruit woodiness virus (PWV) and Cowpea aphid-borne mosaic virus (CABMV), - the latter occurs in Brazil. Infected plants exhibit a mosaic of symptoms, including fruit with hardening of the pericarp, large reduction of the pulp and reduced leaf area and plant vigor. Fruit hardening has already been reported in the major producing Brazilian states (Nascimento et al., 2006) and also in others countries (OchwoSsemakula et al., 2012; Fukumoto et al., 2013).

The in vitro culture of shoot apices is a technique that has been used since 1952 to eliminate viruses and other systemic pathogens in non-arboreal species. This methodology consists on excision of the apical meristematic dome with one or two leaf primordia, followed by culture in a suitable nutritive medium to induce the differentiation and development of the stem and root systems (Souza et al., 2013). Important plant characteristics, such as productivity or vigor, can be either reproduced by crossing or maintained by conventional vegetative propagation techniques or by micropropagation. Some superior genotypes have been used to obtain commercial hybrids of passion fruit, for example, the progenitors of sour passion fruit hybrids BRS Yellow Giant, BRS Savannah Sun and BRS Red Gold, which were released in 2008 by the Brazilian Enterprise for Agricultural Research (Empresa Brasileira de Pesquisa Agropecuária - Embrapa). However, viral contamination of these genotypes is frequent because they are vegetatively propagated.

The effectiveness of eliminating viruses by culturing shoot apices depends on factors such as the type of virus, virushost relationships and especially the size of the shoot apex used (Kartha, 1984). The smaller the explant, the greater the probability of producing contamination-free regenerants; however, the regeneration of smaller explants takes longer and exhibits reduced explant viability (Parmessur et al., 2002).

However, the effective in vitro culturing of passion fruit shoot apices still requires further study, as some authors have reported difficulties in regenerating plants of the genus Passiflora from adult tissues (Drew, 1991; Biricolti \& Chiari, 1994; Becerra et al., 2004).

The aim of the current study was to evaluate in vitro plant regeneration from shoot apices of juvenile and adult passion fruit plants, the establishment ability of shoot apices of different sizes and to provide a basis for future clonal cleanup of superior genotypes using tissue culture methodologies.

\section{Material and Methods}

The experiments were performed in the Tissue Culture Laboratory of Embrapa Mandioca e Fruticultura, located in
Cruz das Almas, Bahia, with plants from the Active Germplasm Bank of Passiflora (AGBP). Studies were divided into three sets of experiments. In the first and second experiments, we assessed the origin and age of the donor plant, the effect of different concentrations of 6-benzylaminopurine (BAP) and the in vitro culture period in the establishment and rooting media. In the third experiment, the establishment of shoot apices of different sizes was evaluated.

Disinfection was performed with $70 \%$ ethanol for 60 seconds, a commercial solution of $25 \%$ sodium hypochlorite $\left(0.5 \%\right.$ active chloride) with three drops of Tween $20^{\circledR}$ for 20 min, and then washed three times with autoclaved water.

Shoot apices of $1 \mathrm{~cm}$ from 1-year-old $P$. edulis plants (AGBP accession 38) kept in a greenhouse or in the field as well as 1-year-old and 8-month-old plants kept in a greenhouse were used as explants in the first and second experiments, respectively. In the third experiment, we used shoot apices of approximately $1,0.5$ or $0.25 \mathrm{~cm}$ from 3-month-old plants of another P. edulis accession (AGBP 158) kept in a greenhouse.

In the first two experiments, the shoot apices were inoculated in MS establishment medium (Murashige \& Skoog, 1962) supplemented with $3 \%$ sucrose and with three concentrations of BAP: 0,1 or $2 \mathrm{mg} \mathrm{L}^{-1}$. In the third experiment, only $1 \mathrm{mg}$ $\mathrm{L}^{-1}$ BAP was used. The media were adjusted to $\mathrm{pH} 5.8$ and autoclaved at $121{ }^{\circ} \mathrm{C}\left(1.05 \mathrm{~kg} . \mathrm{cm}^{-2}\right)$ for $20 \mathrm{~min}$. The media were solidified with $0.2 \%$ Phytagel $^{\circledR}$, and $10 \mathrm{~mL}$ of medium was distributed into test tubes $(150 \times 25 \mathrm{~mm})$.Cultures were maintained in a growth chamber at $27^{\circ} \mathrm{C}$, a photon flux density of $30 \mu \mathrm{mol} . \mathrm{m}^{-2} . \mathrm{s}^{-1}$ and a photoperiod of $16 \mathrm{~h}$.

In the first experiment, the explants were maintained for 60 days in the establishment media and then transferred to MS rooting medium with half-strength mineral salt ( $\left.1 \frac{1}{2} \mathrm{MS}\right)$ supplemented with $1 \mathrm{mg} \mathrm{L}^{-1}$ of indole-3-butyric acid (IBA), in which they were maintained for 21 days in culture.

In the second and third experiments, the time for keeping the explants in the establishment medium was reduced to 26 days and the same time was kept for the rooting medium (21 days). After that, the samples were transferred to $1 / 2 \mathrm{MS}$ medium without growth regulators for 14 days in an attempt to improve the rooting.

After each cultivation phase, the explants were evaluated according to the following variables: percentage of contamination (bacteria, fungi), percentage of explant deaths, height and percentage of rooted explants.

The experiments were performed in a completely randomized design with 15 replicates, and each plot had an explant per test tube. The data were subjected to analysis of variance; when significance was established by the $\mathrm{F}$ test, the treatment effect was submitted to Tukey's test at $5 \%$ probability using the SAS program (Sas Institute, 1990).

\section{Results and Discussion}

The explants from P. edulis plants (AGBP accession 38) that were established in the field showed high contamination rate $(90 \%)$, with $65 \%$ of explants contaminated by fungus and $25 \%$ contaminated by bacteria. For explants that originated from plants maintained under greenhouse conditions, the 
contamination rate was $22 \%$ by fungus and $7 \%$ by bacteria, for a total failure rate of $29 \%$.

These findings are consistent with similar previously published studies. Neem leaf explants derived from fieldestablished plants showed $100 \%$ contamination after disinfection with $10 \%$ or $25 \%$ of a commercial sodium hypochlorite solution (Eeswara et al. 1999), since in the present study also or $25 \%$ of a commercial sodium hypochlorite solution was used and a contamination of $90 \%$ was registered.

In the first experiment, we observed leaf chlorosis in $33 \%$ of the explants prepared from greenhouse-grown plants after 30 days of cultivation and the death of $33 \%$ of the explants due to chlorosis, followed by the necrosis of browning tissues in explants maintained on MS medium with $2 \mathrm{mg} \mathrm{L}^{-1}$ BAP that was observed after 60 days of cultivation. However, during the third month of cultivation, after the explants were transferred to a rooting medium ( $\left.1 / 2 \mathrm{MS}+1 \mathrm{mg} \mathrm{L}^{-1} \mathrm{IBA}\right), 20,33$ and $70 \%$ of explants died in treatments from the establishment medium supplemented with 0,1 and $2 \mathrm{mg} \mathrm{L}^{-1} \mathrm{BAP}$, respectively.

Chlorosis, followed by explant death, might occur due to toxicity caused by the growth regulator and, in that case, lower concentrations should be used. Another aspect to be considered is increasing toxicity observed in explants as the time in the establishment medium increases, indicating a need for reducing that time. Explant death was also observed by Ribeiro et al. (2006) in different types of explants (shoot tip, internodal segment adjacent to the shoot tip, nodal segment adjacent to the shoot tip and leaf tissue) grown from five 7-month-old $P$. edulis accesses after the first week in MS medium supplemented with $2 \mathrm{mg} \mathrm{L}^{-1}$ BAP. Kantharajah \& Dodd (1990) noted similar results in an in vitro experiment of shoot multiplication from $P$. edulis seedlings when the explants were maintained for more than 1 month in medium containing 1 or $2 \mathrm{mg} \mathrm{L}^{-1}$ BAP. Thus, in the second and third experiments, the establishment period was reduced to 26 days.

In the second experiment, performed with explants from 1 -year-old and 8-month-old greenhouse plants, we only observed $13 \%$ contamination in the establishment period $(9 \%$ by fungi and $4 \%$ by bacteria) and $13 \%$ contamination in the rooting period ( $4 \%$ by fungi and $9 \%$ by bacteria), confirming the need to maintain donor sources in cleaner environments, such as screenhouses, greenhouses or growth chambers.

Explant death was observed after 47 days post inoculation (26 days in the establishing medium and an additional 21 days in IBA-containing medium) only for those initially maintained in medium without growth regulators $(20 \%)$, confirming that reduction to 26 days in BAP-containing media was better for explant establishment and survival.

In general, the appearance of the explants in MS medium with $1 \mathrm{mg} \mathrm{L}^{-1}$ BAP was better than those in MS medium with $2 \mathrm{mg} \mathrm{L}^{-1}$ BAP (Figure 1), but the concentration of BAP did not significantly influence the percentage of explants with morphogenic responses for the following variables: explants with developing leaves ( $86.7 \%$ for both BAP concentrations), the average number of leaves per explant and the length of the largest leaf (Table 1). The percentage of rooted explants for those that were cultured previously in establishment medium supplemented with 1 or $2 \mathrm{mg} \mathrm{L}^{-1}$ BAP after 21 days in $1 / 2 \mathrm{MS}$

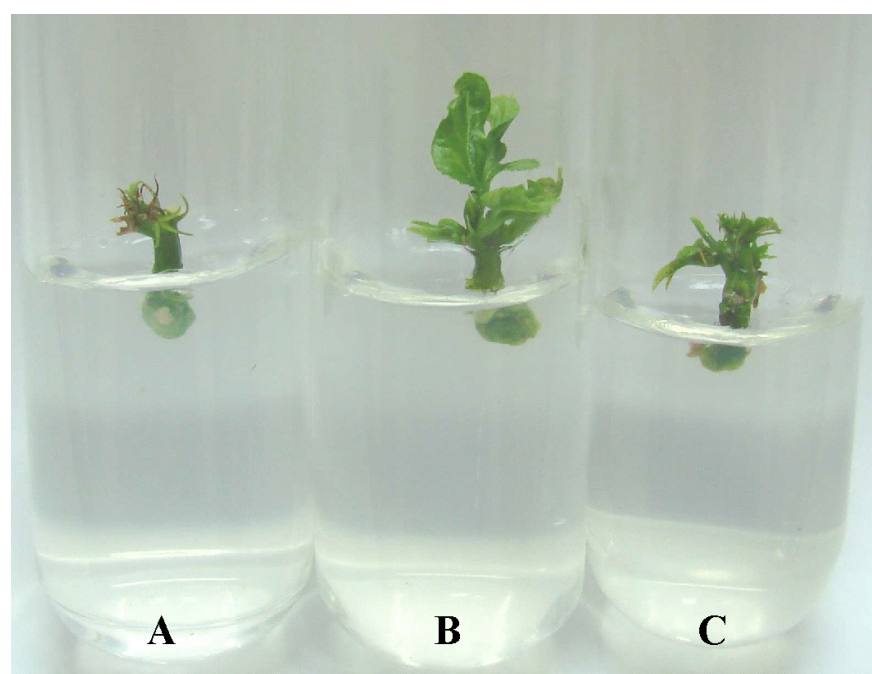

Figure 1. Appearance of $P$. edulis explants (AGBP 38) after 20 days in culture in MS medium (A); MS + $1 \mathrm{mg} \mathrm{L}^{-1} \mathrm{BAP}(\mathrm{B}) ; \mathrm{MS}+2 \mathrm{mg} \mathrm{L}^{-1} \mathrm{BAP}(\mathrm{C})$

Table 1. Explants with developing leaves (EDL), the average number of leaves per explant (ANL) and the average length of the largest leaf (ALL) of P. edulis (AGBP 38) after 26 days in the establishment media MS, MS $+1 \mathrm{mg}$ $\mathrm{L}^{-1} \mathrm{BAP}$ and $\mathrm{MS}+2 \mathrm{mg} \mathrm{L}^{-1} \mathrm{BAP}$ (Experiment 2)

\begin{tabular}{lccc}
\hline Treatment & EDL (\%) & ANL & ALL \\
\hline $\mathrm{MS}$ & - & - & - \\
$\mathrm{MS}+1 \mathrm{mg} \mathrm{L}^{-1} \mathrm{BAP}$ & $86.7 \mathrm{a}$ & $2.17 \mathrm{a}$ & $0.98 \mathrm{a}$ \\
$\mathrm{MS}+2 \mathrm{mg} \mathrm{L}^{-1} \mathrm{BAP}$ & $86.7 \mathrm{a}$ & $2.13 \mathrm{a}$ & $0.95 \mathrm{a}$ \\
\hline $\mathrm{CV}(\%)$ & 21.07 & 14.68 & 10.60 \\
\hline
\end{tabular}

The means corresponding to the same letter in the columns do not differ significantly according to Tukey's test at $5 \%$ probability

medium $+1 \mathrm{mg} \mathrm{L}^{-1}$ IBA was 14 or $20 \%$, respectively, and for those after 14 days of culture after transfer to $1 / 2 \mathrm{MS}$ medium was 36 or $20 \%$, respectively. Therefore, the following protocol was defined as the methodology for the in vitro culture of shoot apices from adult $P$. edulis plants: inoculation of apices in MS medium supplemented with $1 \mathrm{mg} \mathrm{L}^{-1}$ BAP for 26 days for establishment, followed by transfer to $1 / 2 \mathrm{MS}$ medium supplemented with $1 \mathrm{mg}$ $\mathrm{L}^{-1}$ IBA for 21 days of culture and subsequent transfer to $1 / 2 \mathrm{MS}$ without growth regulators for 14 days for rooting.

After finding that it was possible to regenerate $P$. edulis plants from adult material, the third experiment was designed to confirm if it was possible to do so with smaller explants. In this experiment, we observed a 3\% microbial contamination rate in the in vitro establishment phase. One week after inoculation of explants from AGBP accession 158, an early growth of leaf primordia was noted in $97 \%$ of explants in all treatments (Figure 2), and the deaths of only $2 \%$ of the $1-\mathrm{cm}$ explants were observed. There was a clear reduction in root regeneration capacity with the reduced size of the initial explant, and the percentages of rooted explants at the end of the in vitro culture for explants with the initial sizes of $1,0.5$ and $0.25 \mathrm{~cm}$ were 18,5 and $0 \%$, respectively.

Parmessur et al. (2002) reported that smaller explant size increased the probability of obtaining propagation material free of pathogens but with a lower organogenic capacity. A comparison of explants of the same size $(1 \mathrm{~cm})$ revealed that the percentage of rooted explants from AGBP accession 158 was half of that observed for AGBP accession 38. Moreover, at the end of the in vitro culturing procedure, there was a greater 


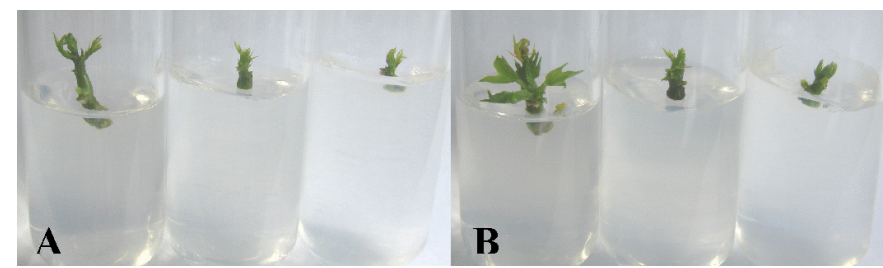

Figure 2. Appearance of $P$. edulis explants (AGBP 158) with initial sizes of $1,0.5$ or $0.25 \mathrm{~cm}$ (left to right) after $14(\mathrm{~A})$ and 26 days (B) in culture in MS medium $+1 \mathrm{mg} \mathrm{L}^{-1}$ BAP

abscission of leaves for AGBP accession 158 compared to AGBP accession 38, which reduces the possibility of success in the acclimatization phase. The opposite behavior was expected because the plants from AGBP accession 158 were 3 months old and those from AGBP accession 38 were 1 year and 8 months old, and younger donor plants have been shown to exhibit higher organogenic ability. However, Prammanee et al. (2011) obtained plants regenerated from explants of $0.2 \mathrm{~cm} \mathrm{P.} \mathrm{edulis} \mathrm{(purple}$ passion). On the other hand Gómez \& González (2010) reported in vitro shoot formation from axillary bud of adult $P$. edulis, but there was no indication of plant regeneration. Thus, it is clear that the organogenic response is also genotype dependent in the accessions from the P. edulis that was used in the present study, which is similar to the results published by Ribeiro et al. (2006) and from Passiflora caerulea by Severin et al. (2011).

The average height of the explants (AGBP 38) from 1-yearold plants after 26 days in vitro culture (Experiment 1) was higher for MS medium $+1 \mathrm{mg} \mathrm{L}^{-1}$ BAP compared to medium without growth regulator, but no difference was observed between culture media used for explants from 1-year-old and 8-month-old plants (Experiment 2) (Table 2). This behavior is most likely due to plant age because older donor plants are less reactive to hormonal stimulation. We only observed an increase in height from 26 to 60 days of culture when there was a decrease in BAP exposure time (Table 3); although the donor plants were older, reducing the time in the establishment medium, followed by media with and without IBA, was the most appropriate culture method.

There was a significant difference in average height for explants from 26 to 58 days of culture with initial sizes of 0.5

Table 2. Average height of $P$. edulis explants (AGBP 38) after 26 days in the establishment media MS, MS $+1 \mathrm{mg} \mathrm{L}^{-1} \mathrm{BAP}$ and $\mathrm{MS}+2 \mathrm{mg} \mathrm{L}^{-1} \mathrm{BAP}$ in the two proposed culture methods (Experiments 1 and 2)

\begin{tabular}{lcc}
\hline \multicolumn{1}{c}{ Treatment } & Experiment 1 & Experiment 2 \\
\hline $\mathrm{MS}$ & $1.18 \mathrm{~b}$ & $1.32 \mathrm{a}$ \\
$\mathrm{MS}+1 \mathrm{mg} \mathrm{L}^{-1} \mathrm{BAP}$ & $1.43 \mathrm{a}$ & $1.32 \mathrm{a}$ \\
$\mathrm{MS}+2 \mathrm{mg} \mathrm{L}^{-1} \mathrm{BAP}$ & $1.19 \mathrm{ab}$ & $1.28 \mathrm{a}$ \\
\hline $\mathrm{CV}(\%)$ & 17.97 & 12.38 \\
\hline
\end{tabular}

The means corresponding to the same letter in the columns do not differ significantly according to Tukey's test at $5 \%$ probability

Table 3. Average height of $P$. edulis explants (AGBP 38) after 26 and 60 days in both forms of in vitro culture (Experiments 1 and 2) for the establishment medium MS $+1 \mathrm{mg} \mathrm{L}^{-1}$ BAP only

\begin{tabular}{ccc}
\hline Days & Experiment 1 & Experiment 2 \\
\hline 26 days & $1.38 \mathrm{a}$ & $1.32 \mathrm{~b}$ \\
60 days & $1.38 \mathrm{a}$ & $1.55 \mathrm{a}$ \\
\hline CV $(\%)$ & 23.03 & 12.95 \\
\hline
\end{tabular}

The means corresponding to the same letter in the columns do not differ significantly according to Tukey's test at $5 \%$ probability and $0.25 \mathrm{~cm}$, which reached average final heights of 0.86 and $0.52 \mathrm{~cm}$, respectively (Table 4 ).

Table 4. Average height of $P$. edulis explants (AGBP 158) after 26 days in medium MS $+1 \mathrm{mg} \mathrm{L}^{-1} \mathrm{BAP}$ and after 58 days with exposure to three types of in vitro culture medium

\begin{tabular}{cccc}
\hline \multirow{2}{*}{ Days } & \multicolumn{3}{c}{ Initial sizes of explants } \\
\cline { 2 - 4 } & $\mathbf{1} \mathbf{~ c m}$ & $\mathbf{0 . 5} \mathbf{~ c m}$ & $\mathbf{0 . 2 5} \mathbf{~ c m}$ \\
\hline 26 days & $1.37 \mathrm{a}$ & $0.75 \mathrm{~b}$ & $0.43 \mathrm{~b}$ \\
\hline 58 days & $1.50 \mathrm{a}$ & $0.86 \mathrm{a}$ & $0.52 \mathrm{a}$ \\
\hline CV $(\%)$ & 13.73 & 14.32 & 18.68 \\
\hline
\end{tabular}

The means corresponding to the same letter in the columns do not differ significantly according to Tukey's test at $5 \%$ probability

However, there was little shoot elongation in any of the experiments. This finding contrasts with the observation of explants that were shoot apices from 13- or 20-day-old $P$. edulis seedlings that reached an average shoot height of approximately $4 \mathrm{~cm}$ after 60 days of in vitro culture, even in the absence of growth regulators (Vidal et al., 2004). For 45-day-old $P$. edulis plants, the average shoot heights in the absence of growth factors were 2.12 and $2.33 \mathrm{~cm}$ after 75 and 105 days of in vitro culture, respectively (Faria et al., 2007). Thus, the small amount of shoot elongation is most likely due to reduction of the morphogenic response caused by reduced juvenility. Becerra et al. (2004) compared juvenile plants $P$. edulis explants to explants from adult plants revitalized by extreme pruning and plants cultured in vitro and concluded that the age of the plants was the most important factor influencing the morphogenic response. For this reason, is generally prefered to obtain explants from seeds germinated in vitro when using different species of Passiflora (Rêgo et al., 2011; Carvalho et al., 2012; Soares et al., 2012).

In addition, Drew (1991) noted the difficulty of the in vitro culture of shoot apices from adult $P$. edulis plants in contrast to the culture of juvenile plants, which grew rapidly in MS medium supplemented with $2.15 \mathrm{mg} \mathrm{L}^{-1}$ kinetin and 0.88 $\mathrm{mg} \mathrm{L}^{-1}$ indoleacetic acid. This difficulty in P. edulis shoot elongation was also reported by Kantharajah \& Dodd (1990), Dornelas \& Vieira (1994), Biasi et al. (2000) and Ribeiro et al. (2006), confirming the difficulty of in vitro propagation of adult $P$. edulis plants.

\section{Conclusions}

It is necessary to add IBA to the medium for the shoots to induce rooting of adult $P$. edulis plants (AGBP accession 38).

The method in which explants are maintained on MS medium supplemented with $1 \mathrm{mg} \mathrm{L}^{-1} \mathrm{BAP}$ for 26 days, followed by transfer to $1 / 2 \mathrm{MS}$ medium supplemented with $1 \mathrm{mg} \mathrm{L}^{-1}$ IBA for 21 days of cultivation, and thereafter for $1 / 2$ MS medium for 14 days, is more appropriate to regenerate plants from shoot apices of adult $P$. edulis plants (AGBP accession 38).

The developed method is cultivar dependent and needs to be adjusted for other AGBP accesses.

\section{Acknowledgements}

The authors acknowledge FAPESB - Fundação de Amparo à Pesquisa do Estado da Bahia for their financial support. 


\section{Literature Cited}

Becerra, D. C.; Forero, A. P.; Góngora, G. A. Age and physiological condition of donor plants affect in vitro morphogenesis in leaf explants of Passiflora edulis f. Alavicarpa. Plant Cell, Tissue and Organ Culture, v.79, n.1, p.87-90, $2004<$ http://dx.doi.org/10.1023/ B:TICU.0000049440.10767.29>.

Biasi, L. A.; Falco, M. C.; Rodriguez, A. P. M.; Mendes, B. M. J. Organogenesis from internodal segments of yellow passion fruit. Scientia Agricola, v.57, n.4, p.661-665, 2000.<http:// dx.doi.org/10.1590/S0103-90162000000400010>.

Biricolti, S.; Chiari, A. Meristem culture and micrografting of Passiflora edulis var. edulis. Advances in Horticultural Science, v.8, n.3, p.171-175, 1994.

Carvalho, M. A. de F.; Paiva, R.; Vargas, D. P.; Porto, J. M. P.; Herrera, R. C.; Stein, V. C. Germinação in vitro de Passiflora gibertii N. E. Brown com escarificação mecânica e ácido giberélico. Semina: Ciências Agrárias, v.33, n.3, p.1027-1032, 2012. <http://dx.doi.org/10.5433/16790359.2012v33n3p1027>.

Dornelas, M. C.; Vieira, M. L. C. Tissue culture studies on species of Passiflora. Plant Cell, Tissue and Organ Culture, v.36, n.2, p.211-217, 1994. <http://dx.doi.org/10.1007/ BF00037722>.

Drew, R. A. In vitro culture of adult and juvenile bud explants of Passiflora species. Plant Cell, Tissue and Organ Culture, v.26, n.1, p.23-27, 1991. <http://dx.doi.org/10.1007/ BF00116605>.

Eeswara, J. P.; Allan, E. J.; Mordue, J.; Stuchbury, T. A procedure for sterilising leaf explants collected from wild neem (Azadirachta indica) trees. Journal National Science Foundation Sri Lanka, v.27, n.2, p.131-136, 1999. <http:// scholar.google. com. br/scholar?hl=ptBR\&q $=\mathrm{A}+$ procedure + fo $\mathrm{r}+$ sterilising + leaf + explants + collected + from + wild + neem $+\% 2$ 8Azadirachta+indica\%29+trees\&btnG=\&lr=>. 29 Mai. 2013.

Faria, G. A.; Costa, M. A. P. C.; Ledo, C. A. S.; Junghans, T. G.; Souza, A. da S.; Cunha, M. P. A. Meio de cultura e tipo de explante no estabelecimento in vitro de espécies de maracujazeiro. Bragantia, v.66, n.4, p.521-526, 2007. $<$ http://dx.doi.org/10.1590/S0006-87052007000400002>.

Fukumoto, T.; Nakamura, M.; Wylie, S. J.; Chiaki, Y.; Iwai, H. Complete nucleotide sequence of a new isolate of passion fruit woodiness virus from Western Australia. Archives of Virology, v.158, n.8, p.1821-1824, 2013. <http://dx.doi. org/10.1007/s00705-013-1670-2>.

Gómez, V. A. O.; González, M. J. D. Regeneración in vitro de Passiflora edulis f. flavicarpa y Passiflora quadrangularis utilizando dos tipos de explantes provenientes de plantas adultas y bencilaminopurina. Revista Científica UDO Agrícola, v.10, n.1, p.23-28, 2010.<http://www.bioline.org. br/pdf?cg10003>. 29 Mai. 2013.

Kantharajah, A. S.; Dodd, W. A. In vitro micropropagation of Passiflora edulis (purple passionfruit). Annals of Botany, v.63, n.3, p.337-339, 1990.

Kartha, K. K. Elimination of viruses. In: Vasil, I. K. (Ed.). Cell culture and somatic cell genetics plants. Gainesville: Academic Press, 1984. p.577-585.
Meletti, L. M. M.; Soares-Scott, M. D.; Bernacci, L. C.; Passos, I. R. S. Melhoramento genético do maracujá: passado e futuro. In: Faleiro, F. G.; Junqueira, N. T. V.; Braga, M. F. (Eds.). Maracujá: germoplasma e melhoramento genético. Planaltina: Embrapa Cerrados, 2005. p.55-78.

Murashige, T.; Skoog, F. A revised medium for rapid growth and bio assays with tobacco tissue cultures. Physiologia Plantarum, v.15, n.3, p.473-497, 1962. <http://dx.doi. org/10.1111/j.1399-3054.1962.tb08052.x>.

Nascimento, A. V. S.; Santana, E. N.; Braz, A. S. K.; Alfenas, P. F.; Pio-Ribeiro, G.; Andrade, G. P.; Carvalho, M. G. de; Zerbini, F. M. Cowpea aphid-borne mosaic virus (CABMV) is wide-spread in passion fruit in Brazil and causes passion fruit woodi-ness disease. Archives of Virology, v.151, n.9, p.1797-1809, 2006. <http://dx.doi. org/10.1007\%2Fs00705-006-0755-6>. 29 Mai. 2013.

Ochwo-Ssemakula, M.; Sengooba, T.; Hakiza, J. J.; Adipala, E.; Edema, R.; Redinbaugh, M. G.; Aritua, V.; Winter, S. Characterization and distribution of a Potyvirus associated with passion fruit woodiness disease in Uganda. Plant Disease, v.96, n.5, p.659-665, 2012. <http://dx.doi. org/10.1094/PDIS-03-11-0263>.

Parmessur, Y.; Aljanabi, S.; Saumtally, S.; Dookun-Saumtally, A. Sugarcane yellow leaf virus and sugarcane yellows phytoplasma: elimination by tissue culture. Plant Pathology, v.51, n.5, p.561-566, 2002. <http://dx.doi.org/1 0.1046/j.1365-3059.2002.00747.x>.

Prammanee, S.; Thumjamras, S.; Chiemsombat, P.; Pipattanawong, N. Efficient shoot regeneration from direct apical meristem tissue to produce virus-free purple passion fruit plants. Crop Protection, v.30, n.11, p.1425-1429, 2011. $<$ http://dx.doi.org/10.1016/j.cropro.2011.07.008>.

Rêgo, M. M. do; Rêgo, E. R.; Bruckner, C. H.; Finger, F. L.; Otoni, W. C. In vitro induction of autotetraploids from diploid yellow passion fruit mediated by colchicine and oryzalin. Plant Cell, Tissue and Organ Culture, v.107, n.3, p.451-459, 2011. <http://dx.doi.org/10.1007\%2 Fs11240-011-9995-6>.

Ribeiro, L. M.; Peixoto, J. R.; Andrade, S. R. M. de; Simões, M. O. M.; Fonseca, R. S.; Vieira, L. M. Organogênese in vitro em acessos de maracujazeiro amarelo infectados pelo vírus CABMV. Unimontes Científica, v.8, n.1, p.87-98, 2006. $<$ http://www.ruc.unimontes.br/index.php/unicientifica/ article/viewFile/169/166>. 29 Mai. 2013.

SAS Institute. SAS/STAT user's guide. Cary: Statistical Analysis System Institute, 1990. 846p.

Severin, C.; Bueno, M.; Santín, F.; Giubileo, M. G. Respuesta in vitro de diferentes biotipos y explantos de Passiflora caerulea L. Revista Colombiana de Biotecnología, v.13, n.1, p.73-79, 2011. <http://www.revistas.unal.edu.co/ index.php/biotecnologia/article/view/22943>. 29 Mai. 2013.

Soares, W. S.; Rêgo, M. M.; Rêgo, E. R.; Barroso, P. A.; Nascimento, K. S.; Ferreira, K. T. Estabelecimento in vitro e micropropagação de maracujá silvestre (Passiflora foetida L.). Revista Brasileira de Plantas Medicinais, v.14, n. spe., p.138-142, 2012. <http://dx.doi.org/10.1590/ S1516-05722012000500002>. 
Souza, A. da S.; Junghans, T. G.; Souza, F. V. D.; Santos-Serejo, J. A. $\quad$ Vidal, A. M.; Junghans, T. G.; Souza, A. da S. Estabelecimento dos; Silva Neto, H. P. da; Menezes, M. C.; Silveira, D. G.; Santos, V. da S. Micropropagação da mandioca. In: Junghans, T. G.; Souza, A. da S. (Eds.). Aspectos práticos da micropropagação de plantas. 2. ed. rev. e amp. Brasília, DF: Embrapa, 2013. p. 345-372. in vitro de maracujazeiro amarelo, acesso BGM 39. In: Congresso Brasileiro de Fruticultura, 18., 2004, Florianópolis. Anais... Florianópolis: SBF, 2004. CD Rom. 